\title{
Prova Campinas 2010: entre usos alegóricos e normativos de linguagem
}

\author{
Antonio Miguel $^{1}$ \\ Anna Regina Lanner de Moura ${ }^{2}$ \\ Lilian Lopes Martin da Silva \\ Norma Sandra de Almeida Ferreira ${ }^{4}$
}

\begin{abstract}
Resumo: A Prova Campinas 2010 foi um trabalho coletivo desafiador. Ao longo dele, fizemos interlocução com práticas cotidianas de ensino que vinham sendo realizadas na rede municipal de ensino de Campinas, bem como com os pensamentos de três destacados filósofos - Friedrich Nietzsche, Ludwig Wittgenstein e Jacques Derrida -, com o propósito de gerar dados que nos permitissem problematizar a educação escolar e as formas habituais de avaliação da aprendizagem nesse contexto. Neste artigo, apresentamos, em linhas gerais, o conjunto de ideias que potencializou os processos de concepção, elaboração e correção da prova, bem como o seu contexto de realização. A apresentação dessas ideias constitui o pano de fundo para o comentário analítico comparativo que nós faremos acerca dos modos como os estudantes que participaram da prova lidam com questões que lhes solicitam fazer usos preponderantemente normativos da linguagem - tais como os que são feitos, dentre outros, pela matemática acadêmica e escolar e com usos preponderantemente alegóricos da linguagem, tais como os que são feitos, dentre outros, pelas diferentes modalidades de artes.
\end{abstract}

Palavras-chave: "Usos alegóricos e normativos da linguagem"; "Prova Campinas 2010"; "Artes"; "Matemática".

\section{Campinas Assessment 2010: between allegorical and normative uses of language}

\footnotetext{
Abstract: The Campinas Assessment 2010 was a challenging collective work. Throughout this work we dialogue with everyday teaching practices that were being held in the municipal

1 Docente do Departamento de Ensino e Práticas Culturais (DEPRAC) da Faculdade de Educação da Universidade Estadual de Campinas-SP (UNICAMP). Membro do Grupo de Pesquisa PHALA: Educação, Linguagem e Práticas Culturais. E-mail: miguel37.unicamp@gmail.com.

2 Docente aposentada do Departamento de Ensino e Práticas Culturais (DEPRAC) da Faculdade de Educação da Universidade Estadual de Campinas-SP (UNICAMP). Membro do Grupo de Pesquisa PHALA: Educação, Linguagem e Práticas Culturais. E-mail: lanner@unicamp.br.

3 Professora da Faculdade de Educação da Universidade Estadual de Campinas-SP (UNICAMP). E-mail: lilian1ms@terra.com.br

4 Professora da Faculdade de Educação da Universidade Estadual de Campinas-SP (UNICAMP). E-mail: normasandra@yahoo.com.br
} 
school system of Campinas, as well as the thoughts of some prominent philosophers - Friedrich Nietzsche, Ludwig Wittgenstein and Jacques Derrida -, in order to generate data that allow us problematize the school education and the usual forms of assessment of learning this context. In this article, we present, in general, the set of ideas that potentiated the processes of design, development and correction of the assessment, as well as its performing context. The presentation of these ideas will be the backdrop for the comparative analytical commentary that we will do about the ways in which students who participated in the assessment deal with questions that ask them to do mainly normative uses of language - such as those made, among others, by the academic and school mathematics - and mainly allegorical uses of language, such as those made, among others, by different types of arts.

Key Words: "Allegorical and normative uses of language”; "Campinas Assessment 2010"; "Arts”; "Mathematics".

\section{Prova Campinas 2010: considerações iniciais}

Embora existam atualmente avaliações já estabelecidas e em uso nas escolas públicas, a SME/Campinas optou pela elaboração de seu próprio processo de avaliação de desempenho, evitando a utilização de matrizes gerais e externas que poderiam não corresponder ao que a rede escolar do município vinha realizando como prática cotidiana ${ }^{5}$.

Assim, em 2007, teve início uma parceria entre profissionais da rede escolar e professores da universidade ${ }^{6}$ que viria a responder pela definição dos princípios orientadores do trabalho, construção de uma prova, elaboração do gabarito de correção, acompanhamento da correção feita por profissionais da própria rede e análise dos resultados.

Esse trabalho culminou na elaboração, aplicação e correção de duas provas (2008 e 2010) envolvendo, em cada uma delas, cerca de três mil alunos dos quartos anos das séries iniciais do Ensino Fundamental. O trabalho como um todo esteve articulado a um processo de formação dos professores que, parceiros, se envolveram nas várias etapas do processo.

Ambas as provas apresentaram distinções importantes em relação a todas as outras avaliações em larga escala que atualmente circulam pela escola: a) em vez de

5 No sentido de articular esforços para a melhoria da qualidade da educação, iniciou-se nas escolas de Ensino Fundamental da rede municipal o processo de avaliação institucional, como uma metodologia que transcende as questões relacionadas apenas com o desempenho do aluno. Foi uma iniciativa pioneira da SME/Campinas em parceria com o LOED - Laboratório de Estudos Descritivos - Grupo de Pesquisas da Faculdade de Educação/Unicamp. Este sistema de avaliação, que está sendo implementado pela SME/ Campinas, é composto por três diferentes módulos: avaliação institucional, avaliação do desempenho dos alunos e censo escolar.

6 Anna Regina Lanner de Moura - (FE/UNICAMP-DEPRAC); Antonio Miguel - (FE/UNICAMP-DEPRAC); Lilian Lopes Martin da Silva - (FE/UNICAMP-DELART); Norma Sandra de Almeida Ferreira - (FE/UNICAMP-DELART). 
avaliar o desempenho individual dos alunos em termos de conteúdos previamente fixados, ou de competências esperadas, as provas tiveram por objetivo conhecer, avaliar e problematizar práticas culturais mobilizadas na escola; b) apoiaram-se em dados colhidos junto aos professores; c) as questões eram dissertativas, distribuídas em dois Cadernos; d) optou-se por uma escala de correção que não se limitou apenas ao certo ou ao errado, mas contemplou cinco diferentes grupos de respostas: em branco; inadequadas; parcialmente adequadas; adequadas; mais elaboradas; e) os corretores foram orientados a assumir a postura de um 'leitor sensível', que se esforça por escutar e interpretar o itinerário de produção das respostas dos alunos; f) foi apresentada uma análise final quantitativa, mas também qualitativa ${ }^{7}$.

A Prova Campinas 2010 - diferentemente da versão 2008, que contemplava apenas as disciplinas de Português e de Matemática - constituiu-se como uma prova indisciplinar, no sentido de que mobilizou os conhecimentos que tradicionalmente fazem parte do percurso escolar inicial, sem considerar seu pertencimento a essa ou àquela disciplina do currículo, aproximando-se, portanto, já em sua organização, da visão apresentada acima e assumida por seus planejadores.

Os descritores estruturantes de sua produção e que também orientaram sua correção foram: a) os usos da linguagem feitos pelos autores dos textos de cada tópico ou questão e aqueles solicitados pelos comandos textuais; b) as práticas referidas por esses comandos; c) os campos de atividade humana mobilizados nos jogos de cena dos textos ${ }^{8}$.

A combinação desses descritores - usos da linguagem, práticas e contextos produz jogos de linguagem ${ }^{9}$. Participar desses jogos - múltiplos e diversificados - é levar em conta os campos de atividade humana, as práticas culturais referidas pelos comandos, os usos da linguagem, pois nada pode ser significado fora ou independentemente desse jogo.

No contexto da Prova Campinas 2010, as crianças faziam uma prova e, portanto, sabiam, a seus modos, que estavam realizando diretamente - e exclusivamente - práticas conjugadas e interdependentes de leitura e de escrita de textos na língua portuguesa, bem como de práticas de visualização de imagens. Assim, participavam de jogos cênico-simbólicos interdependentes de linguagem, orientados por gramáticas diferentes.

7 (Moura, Miguel, Silva \& Ferreira, 2015a); (Moura, Miguel, Silva \& Ferreira, 2015b).

8 (Moura, Miguel, Silva \& Ferreira, 2015b).

9 A expressão jogos de linguagem foi criada pelo filósofo austríaco Ludwig Wittgenstein (1889-1951), na segunda fase de sua obra. Esta noção é bastante explorada em sua obra intitulada Investigações Filosóficas (Wittgenstein 2009; Wittgenstein,1979), publicada postumamente. 
Isso porque, na escola, as múltiplas práticas culturais são sempre referidas ou sugeridas em linguagem, pelos textos. Sejam eles imagéticos ou verbais. Não são práticas culturais diretas - isto é, aquelas que são ou podem ser diretamente realizadas.

Assim, as práticas referidas nos textos da prova não podiam ser diretamente realizadas pelas crianças quando liam esses textos ou quando escreviam respostas em obediência a um comando verbal que lhes era remetido. Era preciso, pela prática da leitura e da escrita, participar dos jogos propostos nos diferentes desafios da prova. Em cada um desses jogos, conjugavam-se elementos distintos que precisavam ser considerados pelos alunos para que a participação fosse coerente e por ela se gerasse uma significação adequada.

Ver alternativamente o propósito da escolarização básica orientado para a problematização de práticas socioculturais que se realizam em diferentes campos e contextos extraescolares de atividade humana, e não para a aprendizagem stricto sensu de conteúdos disciplinares, foi uma das ideias que nos orientou no processo de elaboração da Prova Campinas 2010 destinada às crianças do quarto ano na rede escolar do município de Campinas (SP). Esse olhar alternativo organiza também de outra maneira os processos de mobilização cultural na escola: não mais segundo o critério que opõe os polos genéricos e abstratos forma e conteúdo para concretizá-los e separá-los tematicamente em diferentes disciplinas escolares, mas segundo o critério vivencial que situa e contextualiza dinamicamente o construto indisciplinar práticas culturais em diferentes campos de atividade humana em que são efetivamente realizadas.

Em conformidade com essa nova orientação do olhar, tanto no contexto da Prova Campinas 2010 quanto no deste artigo, não mobilizamos as palavras arte, matemática e educação vendo-as como disciplinas escolares, domínios de conhecimento ou campos de investigação acadêmica, organizados em conjuntos de conteúdos abstraídos de suas formas, desconectados de seus contextos de mobilização e exclusivamente vistos como construtos mentais ou cognitivos. Essa é a forma pela qual nos acostumamos a mobilizar tais palavras, persuadidos pelos efeitos performáticos do poder colonizador secularmente exercido pelo discurso científico e pelo modo disciplinar e hegemônico como ele se instituiu nos processos de escolarização.

Alternativamente, mobilizaremos aqui as palavras matemática, arte e educação como conjuntos de práticas culturais, isto é, como conjuntos de ações corporais diretas orientadas por propósitos e regras que mobilizam mimeticamente saberes, poderes, valores, afetos e memórias. Essa opção, é claro, coloca o corpo humano visto como síntese dinâmica entre natureza e cultura - como o principal arquivo 
memorialístico intangível ${ }^{10}$ das práticas culturais e, portanto, como condição de preservação da diversidade cultural.

\section{Sobre práticas e o caráter indisciplinar das práticas}

Longe de qualquer arbitrariedade ou artificialidade, a possibilidade e legitimidade de se mobilizar as palavras matemática, arte e educação como conjuntos de práticas culturais baseiam-se em rastros de significação de práticas culturais análogas, e muitas vezes homônimas, realizadas por comunidades diversas de outros tempos e de outros lugares. De fato, é referindo-se como uma prática ao conjunto de procedimentos algorítmicos relativos às quatro operações aritméticas usuais, realizadas com base em regras do sistema de numeração decimal, que um anônimo do século XV, dirigindo-se a comerciantes, e não a professores, abre a sua Aritmética de Treviso (Souza, 2004, p.138-140; Swetz, 1989), o primeiro livro impresso de aritmética que começou a circular na Europa a partir do ano de 1478:

Aqui começa uma prática comumente conhecida como o ábaco, muito boa e valorosa para todos que praticam a arte comercial. Eu tenho sido frequentemente procurado por jovens envolvidos com a atividade comercial, interessados em colocar em linguagem escrita os princípios fundamentais da aritmética, comumente chamados o ábaco. Assim, sendo impelido por meu afeto por eles e pelo valor desse objeto, tenho desenvolvido ao máximo a minha pequena habilidade para satisfazê-los, em alguma medida, a fim de que seus louváveis desejos gerem frutos úteis (Swetz, 1989, itálicos nossos).

10 Segundo Wulf (2013, p. 155-169), não se faz atualmente sem conflitos a discussão internacional acerca das características específicas e do papel que o denominado patrimônio cultural intangível (PCI) deveria desempenhar em um mundo globalizado, porém, voltado à preservação da diversidade cultural. As razões por eles elencadas em favor dessa preservação estão todas ancoradas no pressuposto de que o corpo humano é o médium do PCI: 1) os elementos que constituem o PCI - expressões e tradições orais, nelas inclusas o idioma como veículo desse patrimônio; as artes cênico-performativas; as práticas sociais, os rituais e os eventos festivos; o artesanato tradicional etc. - são imateriais e perecíveis e, por essa razão, difíceis de serem identificados, transmitidos e salvaguardados; 2) o corpo é o agente inalienável na realização de qualquer prática social; além dele ser indispensável para se compreender qualquer prática, é o caráter performativo do corpo que faz com que os rituais e outros costumes sociais sejam culturalmentee socialmente efetivos; 3 ) as práticas constituintes do PCI são aprendidas e transmitidas aos jovens através de processos miméticos; 4) a salvaguarda da diversidade cultural está condicionada à sensibilização do outro para valorar positivamente a heterogeneidade cultural; 5) Tal sensibilização está condicionada a se ver os processos educativos como interculturais, transculturais e multiculturais. 


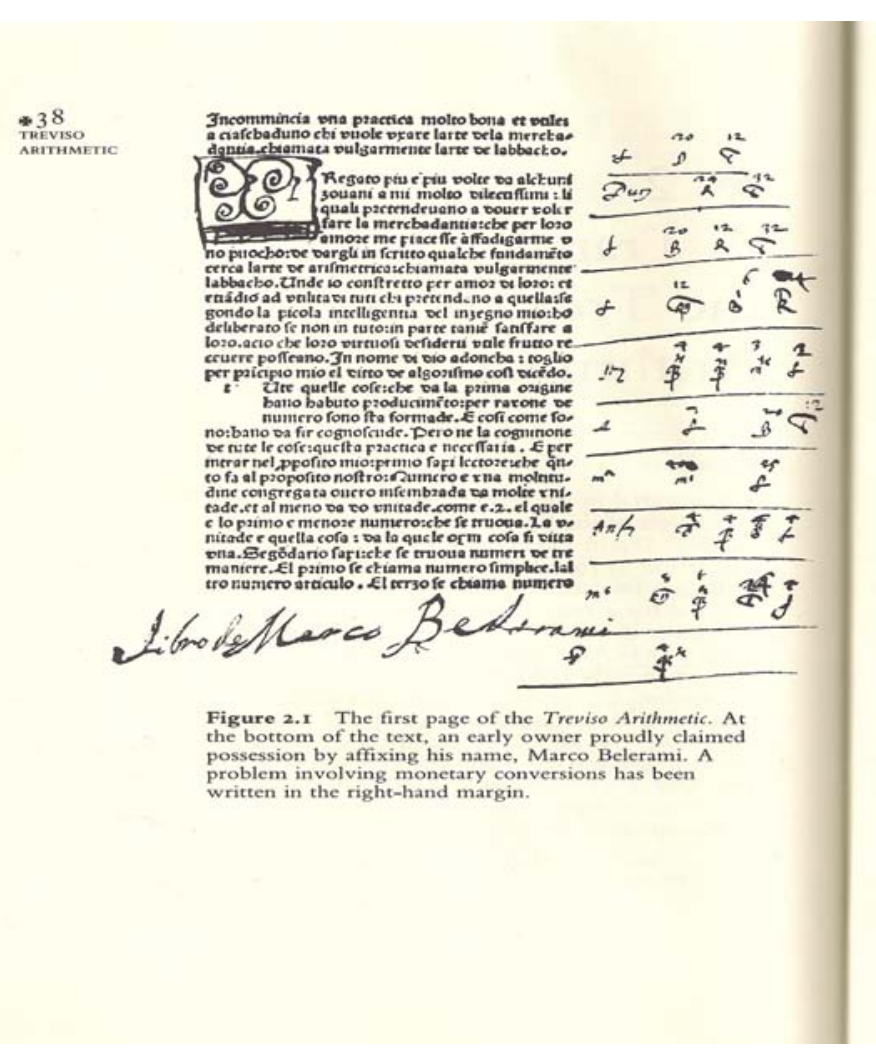

(Swetz, 1989, p. 38)

O fato mesmo de o 'professor' anônimo referir-se à prática do ábaco como uma boa e valorosa prática para os comerciantes evidencia não só o valor conferido por parte dessa comunidade ao saber-fazer corporal do ábaco, agora colocado em linguagem escrita, como também a relativização desse valor para outras comunidades organizadas em outros campos de atividade humana, com base em outros propósitos sociais.

Para outras comunidades tal prática poderia se mostrar não tão valorosa, ou mesmo, desprovida de qualquer valor. A passagem abaixo foi extraída da Aritmética de al-Uqlīdisī, que circulou na cidade síria de Damasco, na segunda metade do século $\mathrm{X}$, com o propósito de divulgar, entre os árabes medievais, a prática escrita do ábaco do modo como já vinha sendo há anos praticada entre os hindus. Ela atesta o valor desigual com que tal prática foi recebida por diferentes comunidades de um mesmo contexto geopolítico, bem como explicita as razões que pareceram a al-Uqlīdisī estar na base da maior ou menor resistência que teria se manifestado nessa recepção:

Muitos homens odeiam mostrar o 'takht' [isto é, o ábaco de areia no qual os hindus escreviam seus algoritmos de cálculo aritmético] em suas mãos [...] por medo de serem mal interpretados por aqueles a quem atendem. Não é decente para eles porque o 'takht' é visto nas mãos dos malcomportados que ganham a sua vida nas ruas, pela astrologia. [...] O escriba, o artesão e o cavaleiro, cada um deles necessita de algo 
com que trabalhar. Se o artesão não tem ou não pode ter (a ferramenta) para com ela trabalhar, ele ficará incapacitado para realizar o trabalho de que necessita. Tendo essa ferramenta [o 'takht'], não haverá dificuldade, sofrimento ou um alto custo [...]. Se outros não gostam dele devido ao pó que suja as mãos e machuca alguns dedos que apagam [a areia], dizemos que podemos usar para isso um estilete curvo para escrever com sua ponta e apagar com o seu verso. Se outros não gostam dele devido ao fato de algumas vezes ser difícil portar um 'takht', ou por ser feio ser visto com ele, uma vez que é feio vê-lo nas mãos do escriba que presta serviços em seu divã nas feiras, dizemos que realizamos [os cálculos] sem que se faça necessário um 'takht' e, portanto, nós o tornamos dispensável para isso. É isso que as pessoas desse ofício fazem, sem 'takht' ou areia, mas sobre uma folha [de papel]. Podemos também escondê-lo através de um recurso que mencionaremos, de modo que a pessoa que vê a outra que calcula com ele não sabe que ele é Hindī, mas pensa que ele é Rūmī (Saidan, 1975, p. 478).

Como assinala Souza (2004, p. 156-158), nesse processo de recepção de uma prática hindu por parte dos árabes, que faziam seus cálculos utilizando-se exclusivamente dos dedos das mãos, não necessitando para isso recorrer a qualquer tipo de artefato mediador como, por exemplo, o ábaco de areia hindu, uma dupla resistência de natureza preconceituosa parece ter ocorrido. Um primeiro preconceito manifestava-se em relação à comunidade dos astrólogos cuja desvalorização se transmitia para a própria prática do cálculo escrito ao modo hindu, valorizada e realizada por essa comunidade de prática. Um segundo preconceito, que também se transmitia à própria prática hindu do ábaco, manifestava-se em relação aos próprios hindus, razão pela qual al-Uqlīdisī se esforça, no prefácio de sua aritmética, para tentar convencer os seus leitores de que seria possível apropriar-se da prática hindu do ábaco desconectando-a de sua origem hindu.

Para isso, al-Uqlīdisī sugere que bastaria substituir o mal visto ábaco de areia hindu - que não apenas sujava os dedos, como também, dava margem ao apagamento pelo vento dos símbolos impressos na areia- por pena, tinta e papel. Esses produtos, vindos de Bizâncio, poderiam não só impedir que os cálculos escritos se apagassem, mas também que se apagasse a memória da própria origem hindu da prática do ábaco. Esse, dentre outros inúmeros exemplos que poderiam ser extraídos do campo dos estudos historiográficos de práticas culturais diversas, nos sugere que as práticas escolares de mobilização cultural, organizadas e classificadas de modo disciplinar desde, pelo menos, o advento dos modernos sistemas de escolarização, manteriam, em grande medida, semelhanças de família com práticas análogas realizadas em outros campos e contextos de atividade humana, com base em propósitos sociais diversos daqueles que teriam orientado e/ou vêm orientando as suas mobilizações escolares disciplinares. 
De fato, com base na investigação historiográfica conduzida por Cohen (1982), relativa ao processo de constituição da aritmética como uma disciplina escolar na Inglaterra do século XVIII, Lave acusa o tipo de transformação abstracionista e redutora por que passaram certas práticas culturais valorizadas em outros contextos (Miguel, 2014) - no caso, práticas comerciais envolvendo quantificação - quando atravessam os muros da escola e se conformam a outros propósitos sociais:

O ensino de aritmética foi introduzido nas escolas elementares britânicas, por volta de 1750 , e trazido para dentro da escola a partir do mercado. O currículo consistia no que Cohen chama "matemática concreta" - sistemas de pesos, medidas e seus equivalentes, para diferentes ramos do comércio. O comércio fornecia os meios de estruturação para o currículo escolar, organizando atividades cotidianas de professores e crianças. [...] Por volta de 1820, o currículo de matemática nos Estados Unidos já não se parecia tanto com um levantamento das práticas quantitativas do mundo dos ofícios e do comércio, e começou a assumir uma estrutura institucionalizada própria (lições de matemática sobre adição, depois subtração, multiplicação e regra de três). O currículo já não era mais organizado especificamente em termos mercantis, embora ainda estivesse sujeito a controvérsias devido às suas conexões comerciais (Lave, 2003, p. 99).

Este comentário de Lave baseado na pesquisa de Cohen interessa-nos aqui por uma outra razão, qual seja, a de acusar a virada conceptual de um currículo de aritmética escolar que dialogava direta e dinamicamente com o campo de atividade comercial e, portanto, com certas práticas comerciais em circulação no mundo europeu por volta de meados do século XVIII, para um outro de natureza conceitual, sequencial e cumulativo, rigidamente organizado com base em conteúdos fixos dissociados de suas práticas.

A partir de meados do século XIX, essa nova forma de organização curricular disciplinar seria aperfeiçoada e legitimada pelo endosso do selo positivista que não apenas inflacionou e segmentou o currículo escolar com um sem número de disciplinas científicas propriamente ditas, como também elevou o ponto de vista cientificista e historicista linear de Auguste Comte a modo científico único de mobilização de conhecimentos no interior da escola.

Entretanto, se nas palavras anteriormente destacadas do anônimo de Treviso, o ábaco era visto como uma prática do campo do comércio concebido como uma arte - o que atesta a atualidade, mesmo na segunda metade do século XV, da tradição grega de assimilar as artes às técnicas ${ }^{11}$-, Comte não reservou às artes lugar algum

11 "Para os gregos, techné era tanto a técnica quanto a arte. A cultura latina traduziu techné por technica, mas também por ars" (Condé, 2009, p. 115). 
em sua enciclopédia do saber, como também não as previu como constituintes do processo de escolarização.

\section{Corpo, práticas e jogos de linguagem no contexto da Prova Campinas 2010}

Além da noção de práticas culturais que se realizam em diferentes campos extraescolares de atividade humana, outro descritor igualmente importante que integrou a matriz de referência para a produção e análise das respostas das crianças da Prova Campinas 2010 foi a noção de usos da linguagem feitos nos textos e requeridos pelos comandos textuais associados aos textos. Tal noção está diretamente associada com a noção wittgensteiniana de jogos de linguagem, a qual, por sua vez, se conecta à de práticas culturais pelo papel central que em ambas desempenha o corpo humano. Se não podemos falar em práticas sem imediatamente pensar em um sujeito corporizado que as realiza, também não é possível pensar em jogo de linguagem sem pressupor sujeitos corporizados que participam do jogo. Assim, os jogos de linguagem, para Wittgenstein, não se reduzem a jogos de fala ou a jogos de escrita em uma língua nacional. Eles seriam mais bem caracterizados se vistos como jogos de encenação corporal nos quais um ou mais participantes realizam uma prática cultural qualquer, tal como, por exemplo: dirigir um automóvel, cantar uma canção, nadar, tocar piano, realizar a divisão de um número por outro, recitar um poema, jogar xadrez, jogar futebol etc.

Assim, a noção de jogo de linguagem se baseia em modos cênico-dinâmicos não exclusivamente linguísticos de usos da linguagem. No sétimo parágrafo das Investigações Filosóficas, Wittgenstein (1979) diz: "Na práxis do uso da linguagem, um parceiro enuncia as palavras, o outro age de acordo com elas. [...] chamarei de jogos de linguagem o conjunto da linguagem e das ações com as quais está interligada”.

Assim, a linguagem vista como práxis sugere que praticar um jogo de linguagem se assemelha a participar de uma encenação, de uma performance corporal efetiva. O que Wittgenstein está querendo dizer com isso é que sempre praticamos a linguagem com o corpo todo, e não apenas com a vibração culturalmente regrada de sons emitidos por nossas cordas vocais (Miguel, 2015).

As noções de práticas culturais e jogos de linguagem, quando combinadas tal como o fizemos no contexto da Prova Campinas 2010, nos permitiram ver dinamicamente a educação e os processos de formação em geral - escolares ou extraescolares - como um conjunto de práticas indisciplinares, porém disciplinadoras, de gestão e autogestão intercultural do corpo humano em e por jogos de linguagem que se processam em diferentes campos de atividade humana, dentre eles, o campo de atividade educativa escolar. Elas nos permitiram, também, ver de outra maneira as 
próprias disciplinas escolares como modos característicos e tipicamente recorrentes de se fazer certos usos da linguagem referidos a domínios especificados de objetos e/ou problemas investigados. Por exemplo, a disciplina de Língua Portuguesa, quando enfocada em sua dimensão literária, poderia ser vista como fazendo os mesmos usos preponderantemente alegóricos da linguagem que os feitos pelas disciplinas artísticas, ainda que tais usos, no domínio da Literatura, se apliquem quase que exclusivamente a textos escritos. Nesse sentido, a legitimidade da aproximação entre obras literárias e obras artísticas de qualquer natureza (arquitetônicas, escultóricas, plásticas, gráficas, fotográficas, cênicas, coreográficas, musicais, fílmicas etc.) estaria baseada nos efeitos performáticos inusitados, surpreendentes e originais que tanto obras literárias quanto artísticas objetivam produzir.

Por outro lado, demo-nos conta de que, em sua dimensão gramatical, a disciplina de Língua Portuguesa acabava fazendo usos da linguagem bastante próximos àqueles feitos pela disciplina de Matemática, quais sejam, usos normativos e convencionais da linguagem que funcionam como padrões de correção da interação comunicativa, dos atos de fala e da produção e organização de textos orais ou escritos em suas dimensões ortográfica, sintática, semântica e estilística. Além disso, dado serem as práticas culturais e os jogos de linguagem construtos indisciplinares, ver a matemática escolar como um domínio de conhecimento que faz usos preponderantemente normativos da linguagem, levou-nos à possibilidade de se distinguir, dentre o conjunto ilimitado de práticas culturais que se realizam em diferentes contextos extraescolares de atividade humana, certos tipos de práticas que se realizam para contemplar um propósito social inequívoco, tal como é o caso, por exemplo, de práticas de orientação espacial realizadas por um piloto de avião com o propósito de conduzir, com segurança, os passageiros de sua aeronave de uma cidade de partida a outra de destino.

Com base nessa distinção, pareceu-nos permissível passar a ver um amplo conjunto de práticas culturais extraescolares não usualmente consideradas "matemáticas”, mas que também poderiam ser incluídas nessa denominação. Dada, porém, a natureza indisciplinar dos descritores analíticos constitutivos da Prova Campinas 2010, em vez de estendermos o regime disciplinar às práticas culturais extraescolares, pareceu-nos mais apropriado estabelecer algumas distinções entre diferentes usos da linguagem feitos nos textos e/ou requeridos pelos comandos textuais.

Nesse sentido, acordou-se que, num texto da prova - fosse ele estritamente verbal, imagético ou híbrido -, se estaria fazendo usos preponderantemente alegóricos da linguagem, sempre que a mobilização de temas, conteúdos, informações, enredo, figuras, objetos, pessoas, personagens, cenas, imagens, cores, legendas etc., no texto, fosse intencionalmente feita através de recursos predominantemente figurativos, isto é, através das denominadas figuras de linguagem, dentre muitos outros 
recursos visuais e/ou sonoros análogos mobilizados no campo das artes em geral, tais como: metáfora, metonímia, prosopopeia, hipérbole, sinestesia, ironia, humor, ambiguidade, catacrese, perífrase, antítese, eufemismo, onomatopeia, aliteração, elipse, pleonasmo, polissíndeto, assíndeto, silepse, anáfora, rima etc.

Com base nesse acordo relativo ao uso da expressão usos alegóricos da linguagem no contexto da prova, nem todo texto verbal, imagético ou híbrido foi visto como preponderantemente alegórico (ou figurativo ou aforístico), ainda que, mesmo com base em linhas argumentativas diferentes, alguns dos principais autores - Ludwig Wittgenstein, Jacques Derrida e Friedrich Nietzsche - com os quais estabelecemos interlocução ao longo do processo de elaboração da prova entendam que a produção performática ou idiossincrática de significados, em todo uso da linguagem, sempre se realize pelo tropo da analogia ou verossimilhança, isto é, por comparações mimético-remissivas entre duas ou mais situações, eventos ou estados de coisas atravessados pela linguagem.

De fato, o perspectivismo filosófico de Nietzsche, orientado pela vontade de potência, ao romper com toda concepção essencialista da significação, passa a vê-la, sobretudo em sua crítica da linguagem após o Zaratustra, sempre como um processo ficcional, sendo a ficção por ele vista como o recurso analógico - o como se, o faz de conta que - e, portanto, como a máscara que movimenta todo processo cênico criador de significados, em que - 'criação' - “tem certa sinonímia com verossimilhança, entendida esta enquanto verdade sem símile, isto é, sem um escalonamento prévio do que seja "a” realidade além do valor que confere a si mesma" (Suarez, 2011, p. 132, itálicos da autora). Os seguintes aforismos nietzschianos ilustram essa concepção ficcional do caráter performático inerente ao próprio processo de produção de significados:

Parmênides disse: "não se pensa o que não é" - estamos no outro extremo e dizemos: o que pode ser pensado há de ser, seguramente, uma ficção (Nietzsche, 2008, § 539).

"Mas por que não seria o mundo que nos concerne uma ficção?"

"E a ficção não requer um autor?"

"Por quê? Este 'requer' não pertenceria também à ficção?" (Nietzsche, 2001).

Nesse sentido, segundo Suarez, "o círculo ficcional do pensamento nietzschiano através da crítica da linguagem se completa assim: a crítica da linguagem só pode ser enunciada até o fim, radicalmente, por um autor que seja personagem, sendo também ator e encenador" (Suarez, 2011, p. 146, itálicos da autora). Entretanto, ao caracterizar os próprios processos vitais como organicamente orientados pelo 
desejo criador da vontade de potência o qual, para ser satisfeito, precisa operar mimeticamente, a ficção é vista por Nietzsche, não como um recurso negativo, mas como uma espécie de ‘distorção' necessária advinda de uma força orgânica que nos impeliria a interpretar previamente a natureza, os eventos, os estados de coisas:

Para o nosso olho é mais cômodo, numa dada ocasião, reproduzir uma imagem com frequência já produzida, do que fixar o que há de novo e diferente numa impressão: isto exige mais força, mais "moralidade". Ouvir algo novo é difícil e penoso para o ouvido; ouvimos mal a música estranha. Quando ouvimos uma língua estrangeira, tentamos involuntariamente modelar os sons em palavras que soem familiares e próximas (...). Assim como atualmente um leitor não lê todas as palavras (e muito menos as sílabas) de uma página - em vinte palavras ele escolhe umas cinco ao acaso, "adivinhando" o sentido que provavelmente lhes corresponde -, tampouco enxergamos uma árvore de modo exato e completo, com seus galhos, folhas, cores e figuras; é bem mais fácil para nós imaginar aproximadamente uma árvore. Mesmo nas vivências mais incomuns agimos assim: fantasiamos a maior parte da vivência e dificilmente somos capazes de não contemplar como "inventores" algum evento. Tudo isso quer dizer que nós somos, até a medula e desde o começo, habituados a mentir. Ou, para expressá-lo de modo mais virtuoso e hipócrita, em suma, mais agradável: somos muito mais artistas do que pensamos ${ }^{12}$.

Há uma força em nós que nos faz perceber com mais intensidade os grandes traços da imagem do espelho, e é de novo uma força que acentua o mesmo ritmo, para além da imprecisão real. Ela deve ser uma força da arte, pois é criadora. Seu meio principal é omitir, não ver e não ouvir. Logo, ela é anticientífica, pois não presta igual atenção a todo o percebido ${ }^{13}$.

Desse modo, em Nietzsche, tudo se passa como se uma suposta força vital performático-interpretativa atuasse como mimese artístico-ficcional produtora de novas significações e aparições do objeto em consideração. Nas palavras de Suarez (2011, p. 152),

Nietzsche usa os seguintes termos como equivalentes: ficcionar - literalmente, "poetizar" (erdichten) -, imaginar, fantasiar (phantasieren), mentir (lügen), inventar (erfinden). No geral, o sentido do texto é que nós vemos o mundo com "licença poética" ("somos mais artistas do

12 Nietzsche, "Contribuição à história natural da moral", aforismo 192, apud Suarez, 2011, p. 152, itálicos da autora.

13 Nietzsche, Le livre du philosophe/Das Philosophenbuch - coletânea de fragmentos póstumos de 18721873, fragmento 55, apud Suarez, 2011, p. 155, itálicos nossos. 
que pensamos") e que nos enganamos, principalmente, ao julgar que "encontramos" (finden) o mundo que, entretanto, "inventamos" (erfinden), ficcionamos, poetizamos.

Mas se Nietzsche entende que a produção performática de significados pelo discurso filosófico só possa ocorrer mediante a sua transfiguração artística - seja tal transfiguração denominada ficcionalização, metaforização ou alegorização -, Derrida, por sua vez, estenderá essa característica transfiguradora a todo tipo de discurso, ou, em termos derridianos, a toda escritura: "A escritura - seja artística, filosófica, científica, religiosa etc. - é sempre "metafórica”, não havendo nenhum "privilégio" a ser atribuído a nenhum tipo de escritura, pois o que Derrida quer pensar é a "metaforicidade" da escritura, ou seja, da escritura em geral" (Haddock-Lobo, 2011, p. 129).

Dentre a ampla variedade de figuras da linguagem, a eleição, por Haddock-Lobo, do tropo específico da "metáfora” para adjetivar a transfiguração derridiana da escritura, com o propósito de estabelecer semelhanças de família entre o que ele denomina "pensamento úmido" derridiano e "pensamento drag", fica mais bem caracterizada pelo uso que este autor faz do esclarecimento do significado do termo "drag" (abreviação da frase "dressed as a girl"), que acompanha a expressão inglesa "drag queen", prestado a este autor pelo filósofo Gianni Vattimo em uma conversa incidental entre ambos:

Essa anedota verídica não quer dizer que o "pensamento úmido" que quero mostrar aqui é um "pensamento drag", mas alguns traços em comum me fazem pensar sobre a relação entre a figura do travesti e a da metáfora, (des) norteando as investigações sobre a escritura, denunciada por sua "perversão" e "inversão" por Saussure. O que adianto é que, neste capítulo que tratará da metáfora, da escrita alegórica e do estilo - portanto, do "vestir-se", eu não pretendo apresentar a escrita úmida de Derrida como uma escrita drag, mas talvez como uma escrita sempre “dressed as" (Haddock-Lobo, 2011, p. 128).

A pertinência e a potencialidade esclarecedoras dessa analogia demarcam a sutil passagem das substituições semânticas da escritura operadas por inversões metafóricas da polissemia para os travestimentos semânticos da escritura operados por deslocamentos metafóricos da disseminação, que caracterizam os dois momentos da desconstrução derridiana da concepção fonologocêntrica saussureana da linguagem (Haddock-Lobo, 2011, p. 131; Derrida, 1971; Duque-Estrada, 2008).

Além disso, esses travestimentos semânticos por que passa a escritura mediante deslocamentos metafóricos da disseminação permitem a Derrida estender em outro sentido o ponto de vista de Nietzsche, deixando de ver o caráter ficcional ou 
alegórico da escritura em geral como sendo obra exclusiva produzida pelo poder performático do discurso artístico ${ }^{14}$. A extensão desse poder performático à escritura em geral é feita mediante o abandono, por parte de Derrida, das noções saussurianas de significado e de significante, a partir do qual ele passa a falar simplesmente em pensamento de rastros ou em jogos de rastros (Haddock-Lobo, 2008, p. 75-79), para destacar o fato de que os processos desconstrucionistas de rastreamento de significados são sempre iterativos, remissivos, referenciais, analógicos e ilimitados:

O significado funciona aí desde sempre como um significante. A secundariedade, que se acreditava poder reservar à escritura, afeta todo significado em geral, afeta-o desde sempre, isto é, desde o início do jogo. Não há significado que escape, mais cedo ou mais tarde, ao jogo de remessas significantes, que constitui a linguagem. $\mathrm{O}$ advento da escritura é o advento do jogo; o jogo entrega-se hoje a si mesmo, apagando o limite a partir do qual se acreditou poder regular a circulação de signos, arrastando consigo todos os significados tranquilizantes, reduzindo todas as praças-fortes, todos os abrigos do fora-de-jogo que vigiavam o campo da linguagem. Isto equivale, com todo o rigor, a destruir o conceito de "signo" e toda a sua lógica. Não é por acaso que esse transbordamento sobrevém no momento em que a extensão do conceito de linguagem apaga todos os seus limites (Derrida, 2008, p. 8 , itálicos do autor).

Por sua vez, para Wittgenstein, o significado de algo não está nesse algo, não constitui uma propriedade ou essência fixa e imutável desse algo, de modo que o que orienta a produção performática e idiossincrática de significados de algo é o uso que fazemos desse algo em jogos de linguagem. Nas palavras de Glock, para Wittgenstein,

a gramática determina que espécie de objeto alguma coisa é, uma vez que especifica o que pode ser dito com sentido sobre ele. [...] A resposta à pergunta socrática “O que é X?" não nos é dada pelo exame de essências (objetos mentais ou abstratos), mas pelo esclarecimento do significado de "X" que é fornecido pelas regras para o uso de "X" (Glock, 1998, p. 195, itálicos do autor).

14 Por essa razão, em sua caracterização do pensamento úmido derridiano, Haddock-Lobo dá destaque ao ponto de vista de Geoffrey Bennington de que "todo conceito não é mais do que "metáfora" levada até o limite marcado pela catacrese" - figura esta que, devido à impossibilidade de se atribuir um significado preciso e adequado a algo, recorre, para isso, a um termo impróprio -, bem como à proposta deste autor de substituir o tropo da "metáfora" pelo da "catacrese" "para indicar que a escrita derridiana apresenta-se através de figuras que não podem conduzir de modo algum a um sentido próprio, como se pode fazer ao indicar uma certa "verdade" da metáfora" (Haddock-Lobo, 2011, p. 130). 
Para Wittgenstein, significações só podem ocorrer mediante o estabelecimento de semelhanças de família entre dois ou mais jogos de linguagem, uma vez que, sendo cada jogo de linguagem um jogo, e não podendo haver um elo significativo que seja comum ou invariante a todos os jogos de maneira que possamos definir o que seja um jogo, a significação só pode ocorrer por semelhanças ou analogias (Wittgenstein, 1979).

Desse modo, diferentemente de Derrida, para Wittgenstein, nos processos de produção de significados por rastreamentos ficcionais ou alegóricos baseados na verossimilhança, um jogo de linguagem (ou uma reencenação da escritura, para Derrida) é visto mais como um jogo completo, singularmente iterável e produtor de diferenças ou inovações a cada nova performance contextualizada desse jogo do que, propriamente, como iterativo e performático em um sentido estrutural e genérico, como pensa Derrida. Isso porque, para este último autor, a característica da iterabilidade parece ser vista como uma estrutura primordialmente repetitiva de signos que, por não tratar-se de uma repetição empírica, não poderia efetivamente ocorrer. Já para Wittgenstein

as práticas de linguagem são performáticas, pois elas não meramente transmitem informação ou comunicam significados, mas também performam ações cujos significados dependem da possibilidade de serem conectadas, através de convenções, com outras ações e eventos (McDonald, 2001, p. 35).

Em relação ao ponto de vista comum entre eles de que a linguagem é um processo temporal repetitivo e singular, a compreensão wittgensteiniana de temporalidade é mais ampla que a de Derrida, uma vez que, de acordo com tal compreensão, "as características repetitivas e singulares da linguagem [são vistas] como uma variável contingente sobre atos de iteração produzidos em práticas discursivas particulares” (McDonald, 2001, p. 35).

No contexto da Prova Campinas 2010, a interlocução que estabelecemos com esses três filósofos cujos modos idiossincráticos e originais de pensamento nos mostravam acentuadas semelhanças de família, nos levou a produzir questões, com seus respectivos gabaritos de correção, e a olhar para as respostas dos alunos com base no ponto de vista pós-epistemológico de não mais se poder pensar o conhecimento independentemente da linguagem, bem como o de se pensar os processos de significação e de formação como modos ou estilos de autogestão mimético-performática do corpo humano em e por jogos situados de linguagem.

Nesse sentido, Nietzsche nos levou a ver os processos de significação e produção de conhecimento como performances artístico-visuais de natureza cênico- 
-ficcionais do corpo humano, de modo que a palavra representação na expressão "conhecimento como representação" deveria passar a ser significada literalmente como "representação cênico-corporal" efetiva ${ }^{15}$.

Wittgenstein, por sua vez, nos levou a reforçar esse aspecto cênico-corporal no modo de significar a palavra "representação", não só despindo-a de suas conotações mentalistas, cognitivistas ou sociológicas - que usualmente a veem como uma mediação entre um suposto mundo mental autônomo de sujeitos incorpóreos ou abstratos e um suposto mundo igualmente genérico, abstrato, homogêneo e totalizante da "práxis social" de qualquer sujeito -, mas vendo-a, sempre, como representação cênico-corporal situada em jogos de linguagem que se processam em formas culturais de vida humana, orientados intencionalmente ou não por regras.

Falar, porém, em autogestão corporal de produção de significados a práticas e saberes como modos ou estilos de representação cênico-corporal em jogos de linguagem que se encenam em "palcos" - sempre orientados por "scripts" gramaticais - de diferentes formas culturais de vida humana significou, para nós, inverter e deslocar a estratégia nietzschiana do "golpe de teatro" de Zaratustra: não só a extensão mimética do estilo cênico-alegórico da forma de vida do teatro para significar os processos de autogestão corporal de produção de significados a práticas e saberes encenados nas demais formas culturais de vida humana, mas também, a extensão mimética do estilo cênico-lúdico que enforma (isto é, que dá visualmente forma) o desenvolvimento de "scripts" gramaticais (isto é, conceituais, intencionais e regrados) que orientam as encenações desses processos nas demais formas de vida à própria forma de vida do teatro.

De fato, de acordo com Condé (2009, p. 123), “em Wittgenstein, além da concepção de conhecimento como gramática, temos ainda a interessante ideia da concepção de conhecimento como estilo de pintura”. Isso significa que há duas formas ou estilos entrelaçados e nem sempre distinguíveis - o estilo gramatical e o estilo da pintura - de conduzirmos visualmente a autogestão corporal e interativa de produção de significados a práticas e saberes em jogos de linguagem. Esses estilos não podem ser vistos nem como antagônicos, nem como intercambiáveis e nem como redutíveis um ao outro.

15 "O que se torna mais claro desde o Zaratustra, contudo, é em que medida a estratégia põe efetivamente em jogo um "golpe de teatro". A alegação da mentira num contexto orientado para a verdade não apenas tende a abolir os termos conflitantes que lança em indecidibilidade e repulsão; ela abole inclusive o "próprio" sujeito da enunciação. [...] Zaratustra se torna, por conseguinte, "ninguém”. Seu rosto se esfuma sob a máscara [...]. Mas se o rosto de Zaratustra desaparece, então, quem usa a máscara? Ora, as máscaras podem ser usadas por personagens! E também por poetas! [...] Pois a temática de Zaratustra, precedida pela revelação do conluio entre verdade e mentira - relação extramoral e, sobretudo, extrassocial, demolidora, "desmoralizante"- tem que ser suportada por um pensamento que se aproxime do teatro e da ficção!” (Suarez, 2011, p. 131-132, itálicos da autora). 
De acordo com o estilo gramatical, a autogestão cênico-corporal do processo de produção de significados a práticas e saberes em um jogo de linguagem ocorre preponderantemente mediante o seguimento intencional, prévio, racional e afetivamente controlado não só das denominadas "regras do jogo" - isto é, do conjunto explícito e publicamente negociado de propósitos, conceitos, enunciados, princípios e procedimentos valorativos constitutivos do próprio jogo e que, muitas vezes, simplesmente aceitamos porque queremos, precisamos ou somos mesmo forçados a jogar, ainda que possamos estar em desacordo parcial ou total com essas regras -, mas também de "regras fora do jogo", ou melhor, de "regras provenientes de outros jogos”, que acabamos, por alguma razão, nos impondo para jogar. Assim, por exemplo, se queremos jogar xadrez, precisamos ter conhecimento prévio das regras e propósitos publicamente acordados orientadores do jogo, a fim de planejarmos estratégias adequadas de ação e reação.

Por sua vez, de acordo com o estilo da pintura, a autogestão cênico-corporal do processo de produção de significados a práticas e saberes em um jogo de linguagem ocorre preponderantemente mediante ações corporais miméticas ${ }^{16}$ - simultaneamente sensórias, perceptivas, cognitivas, afetivas etc., caso ainda queiramos recorrer a esse tipo de terminologia empirista impropriamente dissociativa - que se orientam por verossimilhança remissiva e conexiva a práticas e saberes precedentemente encenados, vivenciados e memorizados que participam do patrimônio cultural intangível da humanidade (Wulf, 2013, p. 153-172).

\section{Usos preponderantemente alegóricos e preponderantemente normativos da linguagem na Prova Campinas 2010}

O estilo gramatical e o estilo da pintura não devem ser assimilados a pares dicotômicos tradicionais - tais como: teoria versus prática; ação versus contemplação; mental ou espiritual versus corporal; racional versus empírico; perceptual versus racional; especializado versus vulgarizado; escrito versus oral ou visual; elaborado

16 Segundo (Gebauer \& Wulf, 2004, p. 129-130), "a mimese, enquanto capacidade de compreender, expressar e representar formas de comportamento humano, ações e situações, registra as normas institucionais e individuais presentes em situações e ações sociais sem que estas sejam conscientes ao agente. As crianças já imitam desde cedo ações complexas e simbolicamente codificadas sem ter consciência destas e dos valores e normas contidas nelas. Como apropriação de posições, valores e competências executadas pela percepção esbarra em diversos moldes referenciais, os resultados da mimese social também irão diferenciar-se em cada homem. De um lado, atua nestes processos uma tendência determinista que aponta para uma recepção exata das formas de ação e comportamento. Por outro lado, estes processos contêm um momento de formação e liberdade individuais que provoca a imprevisibilidade dos resultados da mimese social". 
versus vulgarizado etc. - usualmente acionados por paradigmas hegemônicos de pesquisa no terreno das ciências humanas. Eles próprios não podem ser vistos como dicotômicos e sempre ocorrem simultaneamente, ainda que em graus diferenciados de intensidade e complexidade, em qualquer processo de autogestão cênico-corporal de produção de significados a práticas e saberes em jogos de linguagem. Por exemplo: um pianista virtuoso executa uma peça musical de alto grau de elaboração e complexidade técnicas e afetivas com base, sobretudo, no estilo mimético da pintura. Também o elaborado e complexo modo aforístico-terapêutico de filosofar acionado pelo próprio Wittgenstein em seus escritos é praticado, sobretudo, com base no estilo mimético da pintura, dado que a abordagem terapêutica wittgensteiniana de um problema filosófico assemelha-se ao processo dinâmico, não linear, não causal e sempre inconcluso de justapor fragmentos imagéticos heterogêneos e independentes, representativos de diferentes modos perspectivos de ver o problema em foco, visando à produção de uma obra artístico-visual compósita que possibilite uma visão panorâmica do mesmo ${ }^{17}$.

Entretanto, com base nas considerações comparativas que fizemos sobre os pensamentos dos três filósofos com os quais estabelecemos interlocução, é razoável afirmar que o estilo da pintura é mais frequentemente acionado para encenarmos jogos de linguagem orientados por propósitos preponderantemente alegóricos, ao passo que acionamos o estilo gramatical na maior parte das vezes em que participamos de jogos de linguagem orientados por propósitos preponderantemente normativos ou que não podem ser vistos nem como preponderantemente alegóricos e nem como preponderantemente normativos.

No contexto da Prova Campinas 2010, dizemos que um uso da linguagem é orientado por um propósito normativo sempre que tal propósito orienta e/ou define inequivocamente, isto é, sem ambiguidade, o modo considerado correto ou adequado de se proceder, agir e/ou de significar palavras, imagens, ações etc. numa situação especificada. Assim, por exemplo, no Texto 3 do Caderno 1 da Prova Campinas 2010

17 O "estilo da pintura" que orienta a prática de uma terapia wittgensteiniana poderia assemelhar-se, por exemplo, a diferentes imagens instantâneas do ateliê de costura de uma "velha senhora" supostamente intencionada em costurar uma colcha de retalhos, cena imaginária a que fomos remetidos pelo seguinte comentário de Salles: "Na descrição da terapia, é difícil ocultar um certo sentimento de conspiração contra as origens, de método que se anula. Essa negatividade do labor filosófico não é gratuita. Afinal, o filósofo [Wittgenstein] não deixa de dirigir-se a questões que, sem sua ação, talvez jamais fossem colocadas. Opera como que pelo inusitado. Assim, amealha exemplos, como uma velha senhora guardaria farrapos, botões, peças soltas. Não obstante, sempre ofaz com um propósito determinado, mas de tal sorte que sua ação pode ela própria ser o maior sintoma da doença que procura tratar, assemelhando-se o procedimento terapêutico e a doença: "Em certo sentido, a recolha de exemplos é boa; em outro, porém, é o mais seguro sinal da doença filosófica”. Por isso também, repete várias vezes Wittgenstein, o filósofo só pode tratar uma questão como uma doença, não podendo mais haver exatamente um método, mas sim métodos, ou melhor, diferentes terapias" (Salles, 2005, p. 90-91, itálicos nossos). 
se faz um uso normativo da linguagem, uma vez que ele é um mapa representativo das ruas e avenidas do centro da cidade de Campinas que indica inequivocamente não só as posições relativas dessas ruas e avenidas, bem como o sentido obrigatório de percurso dos veículos automotores nessas ruas. Nesse sentido, esse texto imagético possibilita tanto a um pedestre quanto a um motorista orientarem-se espacialmente de um modo inequívoco por essas ruas a fim de localizar e atingir o local desejado de destino. Do mesmo modo, o Texto 5 do Caderno 2 faz um uso normativo da linguagem para explicar à criança o significado que deve ser feito da palavra bullying, no contexto da prova, para que ela possa responder adequadamente aos comandos verbais que lhe são dirigidos em seguida. Assim, torna-se compreensível que os textos matemáticos (mas não só eles) façam sempre usos normativos da linguagem. De fato, para realizar um cálculo com correção, por exemplo, a criança precisa seguir as regras do sistema de numeração decimal, bem como outras que orientam o procedimento algorítmico, ainda que tais regras nem sempre estejam explicitamente enunciadas no texto que lhe solicita a realização do cálculo.

Ainda que essa classificação tripartite dos jogos de linguagem não seja categórica, uma vez que apresenta certa ambiguidade que não pode ser eliminada, foi ela que nós decidimos adotar para distinguir, classificar e caracterizar os diferentes usos da linguagem feitos nos textos e nos comandos textuais relativos a esses textos dirigidos aos alunos na Prova Campinas 2010.

Desse modo, não pudemos incluir a analogia, a similitude ou a verossimilhança como figuras de linguagem, pois, se o fizéssemos, estaríamos borrando toda a distinção que fizemos no contexto da Prova - e também vista por nós como necessária em muitos outros contextos e para muitos outros propósitos sociais - entre usos alegóricos da linguagem, usos normativos da linguagem e usos nem alegóricos e nem normativos de linguagem. Todos os 14 textos que compuseram a Prova Campinas 2010, bem como cada um dos 55 itens dos comandos textuais a eles referentes foram incluídos em uma dessas três categorias. Mesmo quando identificamos um texto como fazendo um determinado uso preponderante da linguagem (normativo, alegórico ou nem/nem), isso não impede que certos comandos verbais referentes a esse texto possam ser identificados como diferentes daquele do próprio texto.

\section{Comentários comparativos sobre a gestão corporal de usos preponderantemente alegóricos ou normativos da linguagem pelas crianças}

Do conjunto de 14 textos que compunham a prova, 7 foram considerados alegóricos por esse acordo estabelecido. Letras de música, pinturas, fragmentos de textos literários etc. Entre os 55 itens ou comandos, que, em torno desses textos, 
solicitavam respostas dos alunos, 11 foram categorizados dessa forma. Solicitavam opiniões, atribuição de nomes etc.

De igual maneira, acordou-se que em qualquer texto se faz um uso da linguagem com propósitos predominantemente normativos toda vez que tal propósito orienta e/ou define inequivocamente, isto é, sem ambiguidade, o modo considerado correto ou adequado de se proceder, agir e/ou de significar palavras, imagens, ações etc. numa situação especificada. Na prova, 4 textos e 23 itens foram entendidos como normativos.

Os demais textos e comandos foram considerados como pertencentes a uma categoria "intermediária”, isto é, se localizariam entre um tipo e outro, num continuum imaginário. O quadro seguinte discrimina, comparativamente, os desempenhos percentuais médios das crianças que realizaram a prova em cada um dos itens que lhes solicitavam fazer usos preponderantemente alegóricos ou preponderantemente normativos da linguagem ${ }^{18}$ :

\begin{tabular}{|c|c|c|}
\hline MÉDIA & $\begin{array}{c}\text { UNIVERSO RESTRITO } \\
\text { A - PA - IN } \\
(\mathrm{A}+\mathrm{PA})-\text { IN }\end{array}$ & $\begin{array}{l}\text { UNIVERSO AMPLIADO } \\
\text { A - PA - IN - B - IL } \\
(\text { A + PA })-(I N+B+I L)\end{array}$ \\
\hline $\begin{array}{l}\text { Média dos índices percentuais } \\
\text { médios em que são feitos usos } \\
\text { normativos da linguagem }\end{array}$ & $\begin{array}{c}(26,7-20,8-52,5) \\
(47,5-52,5)\end{array}$ & $\begin{array}{c}(21,6-16,0-39,3-21,8-1,3) \\
(37,6-62,4)\end{array}$ \\
\hline $\begin{array}{l}\text { Média dos índices percentuais } \\
\text { médios } \\
\text { em que são feitos usos alegóricos } \\
\text { da linguagem }\end{array}$ & $\begin{array}{c}(45,1-20,3-34,6) \\
(65,4-34,6)\end{array}$ & $\begin{array}{c}(39,6-17,5-29,9-10,8-2,1) \\
(57,2-42,8)\end{array}$ \\
\hline
\end{tabular}

Como se pode observar, tanto no universo restrito quanto no ampliado (no qual foram também computadas as respostas em branco ou ilegíveis), o desempenho percentual médio das crianças em itens que lhes solicitam fazer usos normativos da linguagem é expressivamente menor do que em itens que lhes solicitam fazer usos alegóricos da linguagem. Quando consideramos apenas respostas adequadas nesses dois universos, essa relação percentual varia, respectivamente, de 26,7\%/21,6\% a 45,1\%/39,6\%. Já quando consideramos a soma de respostas adequadas e parcialmente adequadas nesses dois universos, essa relação percentual varia, respectivamente, de $47,5 \% / 37,6 \%$ a $65,4 \% / 57,2 \%$.

À primeira vista, o desempenho dos estudantes em usos alegóricos, comparativamente àquele em que lhes era solicitado realizar usos preponderantemente nor-

18 Legenda das siglas: A - Médias de Respostas consideradas Adequadas; PA - Médias de Respostas consideradas Parcialmente Adequadas; IN - Médias de Respostas consideradas Inadequadas; B - Médias de Respostas em Branco; IL - Médias de Respostas consideradas Ilegíveis. 
mativos da linguagem, pode ser considerado muito bom. De fato, quando a um texto cujo uso da linguagem é preponderantemente alegórico soma-se uma solicitação de resposta em que o uso demandado é semelhante, tem-se uma situação que oferece maior abertura às possibilidades de respostas. Então, impõe-se a necessidade de se considerar em maior grau aspectos que remetem à subjetividade dos estudantes, o que exige maior flexibilização do gabarito orientador da correção.

No entanto, quando consideramos os desempenhos médios dos estudantes nesse conjunto, nos deparamos com oscilações que matizam essa aparente 'facilidade'. As porcentagens obtidas em cada item variam muito entre si. Se considerarmos a média desses desempenhos médios nos diferentes itens, poderíamos vê-los como insatisfatórios, pois, na maioria dos 18 itens que compõem esse universo, eles se localizam abaixo da média, com percentuais abaixo de $50 \%$.

Comentário quantitativo análogo poderia ser feito em relação aos desempenhos médios dos estudantes quanto a usos preponderantemente normativos da linguagem. Também eles se mostram bastante instáveis, e quando avaliados em relação à média dos desempenhos médios (47,5\% de respostas adequadas mais parcialmente adequadas no universo restrito) desses usos em todos os 23 itens em que são solicitados, 12 deles são inferiores a essa média.

Esse comentário quantitativo comparativo relativo à instabilidade ou oscilação nos desempenhos percentuais médios em usos alegóricos e normativos poderia ser estendido ao conjunto de todos os 55 itens da prova. Nesse sentido, uma das conclusões surpreendentes evidenciada pela análise quantitativa dos desempenhos das crianças na prova foi que:

o desempenho em se fazer um determinado uso da linguagem varia expressivamente em função dos tipos de práticas culturais que tais usos são solicitados a significar. E, inversamente, o desempenho das crianças em relação a modos considerados adequados de significar uma determinada prática cultural também varia expressivamente em função dos diferentes usos da linguagem solicitados para se produzir significações adequadas a essas práticas (Moura \& Miguel \& Silva \& Ferreira, 2015).

A fim de tentar entender razões que poderiam ter levado a essa flutuação de desempenhos em todos, bem como em cada um dos três tipos considerados excludentes de uso da linguagem - alegóricos, normativos, nem alegóricos e nem normativos -, vamos, em seguida, tecer alguns comentários qualitativos, tomando como referência algumas respostas dadas pelas crianças a alguns itens preponderantemente alegóricos ou normativos da linguagem. Para isso, vamos partir do Texto 7 
do Caderno 2 e do Texto 3 do Caderno 1 da Prova Campinas 2010 ${ }^{19}$, respectivamente transcritos em seguida:

Texto 7 - Compare a tela anterior com o quadro abaixo, pintado por Helena Santos Coelho ${ }^{20}$.

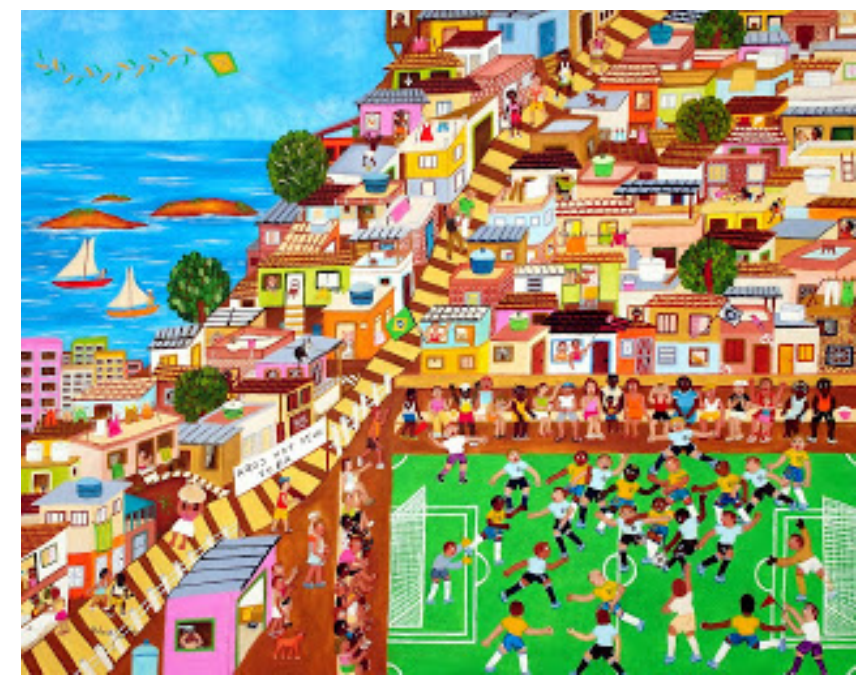

a. Como o futebol está sendo praticado nesta tela? Explique a sua resposta.

b. Que nome você daria a essa tela?

Texto 3 - No mapa seguinte aparecem os nomes de ruas e avenidas do Centro de Campinas.

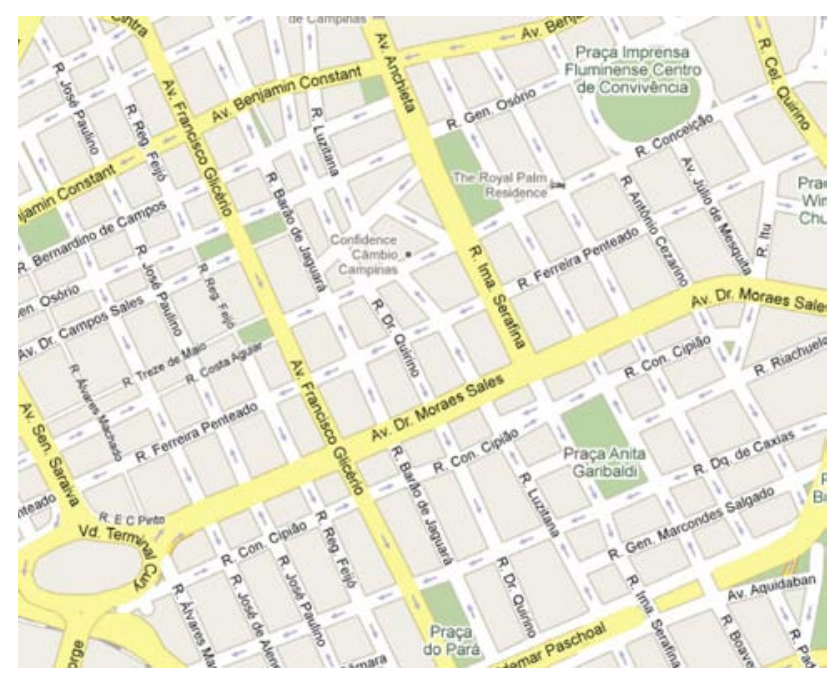

b. Marque no mapa, com a letra A, o cruzamento das ruas Treze de Maio e José Paulino e, com a letra B, o cruzamento das ruas Conceição e Irmã Serafina.

Descreva, em palavras, o menor caminho possível que uma pessoa faria, a pé, para sair do cruzamento A e chegar ao cruzamento B.

19 Os cadernos da Prova Campinas 2010 encontram-se disponíveis em: http://campinas.sp.gov.br/governo/ educacao/depto-pedagogico/avaliacao-institucional/textos.php

20 "Futebol na favela" de Helena Santos Coelho: http://pinturasnaifdehelenacoelho.blogspot.com.br/ 
c. Veja novamente os cruzamentos A e B que você marcou no item anterior. Um motorista de táxi sai do cruzamento A e quer chegar ao cruzamento $\mathrm{B}$, fazendo o menor caminho possível. Descreva, em palavras, esse caminho, sabendo que, no mapa, as flechinhas indicam o sentido obrigatório de percurso dos automóveis nas ruas do centro da cidade de Campinas.

A escolha desses dois textos, dentre outros inclusos na prova, deveu-se ao fato de ambos fazerem usos imagéticos da linguagem, dando-nos, portanto, a possibilidade de estabelecermos comentários cruzados em relação a modos como as crianças lidaram com comandos textuais que lhes solicitavam fazer ora usos alegóricos, ora normativos da linguagem mediados por imagens.

O sétimo e último texto do segundo caderno da prova é uma reprodução da tela pintada por Helena Santos Coelho. O comando do item b desse Texto solicitava um uso alegórico, verbal e informativo da linguagem, exigindo que o leitor se voltasse para a tela de Helena a fim de lhe dar um nome, em uma prática de apreciação estética referente a um assunto (futebol) próprio do contexto desportivo.

A pintura colorida (uma imagem artística) de Helena traz no canto direito a representação 'chapada' de um jogo de futebol em que ele está sendo descrito com marcas tipicamente reconhecidas: campo verde, dois gols, pessoas vestidas como jogadores (uniformizados em cores distintas), em movimento, público sentado a assistir etc. Mas também a pintura tem, em perspectiva, um empilhamento de casas, uma escadaria, um mar, dois barcos, ilhas, pipa no céu. Um morro, com certeza. A autora faz um uso da linguagem por nós definido como sendo preponderantemente alegórico, mas também imagético e descritivo.

O comando do item solicita que se faça um uso alegórico, verbal e informativo da linguagem, exigindo do leitor que ele se volte para a tela de Helena e lhe dê um nome, realizando a apreciação estética de um texto imagético cujo assunto principal parece ser a prática do futebol, pertencente ao contexto desportivo.

Este foi o jogo proposto e que alcançou o maior êxito no conjunto de respostas em que foi feito um uso alegórico da linguagem. A encenação colocada em movimento neste item combinou os elementos: uso alegórico da linguagem; prática do futebol; campo desportivo de atividade humana.

Os alunos, em grande maioria, parecem ter percebido o jogo de futebol como sendo a prática tematizada e sua inserção na situação em que era praticado, como evidencia, por exemplo, a resposta: “A cidade do futebol”. Pode ter contribuído para esse bom desempenho o repertório de experiências dos estudantes referentes ao contexto desportivo, constituído em nossa cultura. Sua compreensão parece ter sido construída na representação que o futebol tem no imaginário nacional ("uma paixão nacional"). De certa forma, a familiaridade dos estudantes com este contexto pode ter contribuído para o êxito da maioria, porém ela não o explica totalmente. 
Os estudantes estão acostumados a realizar diretamente práticas neste contexto desportivo, como por exemplo, jogar ou assistir futebol pela TV. No entanto, nesse caso, a prática do futebol está indiretamente referida pelo "texto imagético" da tela de Helena. E, ao invés de praticar diretamente o futebol ou de assistir a um jogo de futebol pela TV, o aluno é desafiado a manifestar por escrito a sua prática de apreciação estética de uma pintura que encena um instantâneo de uma partida de futebol. Esse poderia ser um elemento de dificuldade.

Mas, a natureza do uso da linguagem feito no comando - alegórico - pode ter também colaborado para o grande êxito alcançado. $\mathrm{O}$ uso alegórico da linguagem contempla uma ampla gama de possibilidades de respostas aceitáveis. Ele procura assegurar a subjetividade dos estudantes. São comandos que, nos manuais dos professores que acompanham os livros didáticos, por exemplo, trazem a informação de que as respostas esperadas são "livres", ou seja, não são passíveis de correção.

Além do mais, os estudantes estão bastante familiarizados, na escola, com o comando "dê um título" e com a prática de apreciação estética, objetivo de avaliação deste item. A inclusão de textos alegóricos no material didático (principalmente reproduções de pinturas, fotos etc., a partir dos anos 80 do século XX) acompanhada de comandos que contemplem posicionamentos mais singulares, particulares ou 'livres' por parte dos estudantes, têm demandado frequentemente práticas de apreciação ou opinativas.

Os estudantes também podem ter sofrido os efeitos do contraste entre uma representação em perspectiva com outra sem perspectiva que projeta na cena o campo de futebol. Essa ausência de perspectiva e de proporcionalidade na representação da prática de futebol produziu um destaque para esta prática, conferindo a ela centralidade na tela e uma espécie de "apagamento" do cenário, também representado. Respostas como as seguintes sugerem essa orientação: “O jogo dos craques"; "O jogo proficional".

Mas esse destaque também pode ter sido completamente ignorado pelos alunos. Respostas como, por exemplo: "o lugar colorido" e o "chumcumbalacobaco" não remetem para a prática do futebol, mas para outros aspectos que compõem a cena. No caso do segundo exemplo, parece que o aluno deslocou-se para um contexto que se distancia do contexto desportivo, mas, que pode remeter a uma novela da Globo com este nome, que é parte do contexto vivido pelo aluno. As duas possibilidades indiciam que o colorido, a mistura e o excesso de elementos presentes na tela podem ter orientado os sentidos atribuídos.

Podemos pensar também que tal êxito se explique pela presença da referência à tela "Futebol na favela" (2009), - Óleo sobre tela, 65X81 cm - Helena dos Santos Coelho (...)", ao pé da mesma página da prova em que estava esse item. O êxito 
alcançado pela maioria dos estudantes poderia ter sido produzido pela cópia da referência?

Outra possibilidade para este êxito pode ser considerada no caso dos estudantes terem respeitado a sequência dos textos e itens na prova. Isso porque, o item a do Texto 7 que antecede o que estamos aqui comentando pede aos estudantes a descrição e explicação de como o futebol está sendo praticado na tela (de Helena), comparando-a com outra, de autoria de Candido Portinari, intitulada Futebol ${ }^{21}$, e que também representa um jogo de futebol acontecendo no chão de terra batido, com "crianças" se movimentando em torno de uma bola. Em volta, bichos domésticos, uma cruz, um pequeno "cemitério", um pouco de verde:

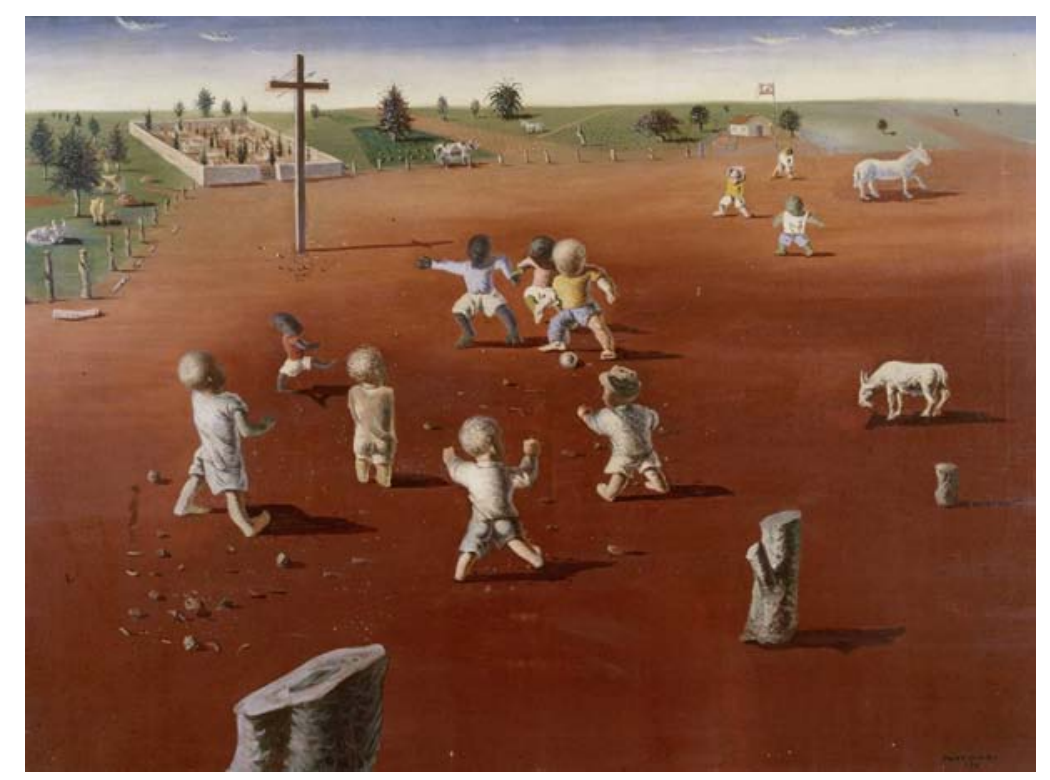

Essa espécie de cadeia estabelece uma interdependência entre itens que torna mais aberta, imprevisível e complexa a autogestão corporal da produção de significados pelas crianças, de modo que a resposta a um deles, entre eles o item b do Texto 7, pode envolver a apreciação de outro(s), bem como remeter a contextos extradesportivos de ancoragem da significação sugeridos pelos dois modos distintos como o futebol é encenado em cada uma dessas telas. Assim, nomear a tela de Helena pode ter se constituído numa ação altamente "controlada” por um conjunto de operações já realizadas anteriormente.

Mais do que constatar o desempenho dos estudantes em qualquer item e atribuí-lo ao domínio ou não deste ou daquele uso de linguagem, entre todos os que são possíveis, - narrativo, descritivo, informativo, normativo, alegórico etc. nosso esforço, na análise de suas respostas ao item b do Texto 7, concentrou-se na busca de interpretações sensíveis para seus modos de participação nas encenações

21 Tela "Futebol" de Cândido Portinari: http://www.portinari.org.br/\#/acervo/obra/1127/detalhes 
propostas, suas formas de significação. Considerando aspectos relacionados às práticas envolvidas bem como os campos de atividade humana a que se referem; ao contexto cultural em que se situam os estudantes; à materialidade da prova, e sua narratividade; a aspectos da cultura escolar.

Por sua vez, o Texto 3 do Caderno 1, que mobiliza a imagem de um mapa rodoviário das ruas do centro de Campinas - fazendo usos da linguagem por nós definidos como simultaneamente normativo, imagético e informativo -, foi o que apresentou maior dificuldade para as crianças relativamente a usos normativos da linguagem: os desempenhos médios, no universo restrito, em respostas consideradas adequadas, relativos aos itens c e b, foram, respectivamente $2,3 \%$ e $2,8 \%$. O que está em jogo nos dois comandos textuais relativos a este texto é a verificação de uma suposta competência das crianças em práticas de orientação e deslocamento espaciais, mediadas por um mapa, em ruas do centro de Campinas.

Vamos considerar, em seguida, algumas respostas - todas consideradas inadequadas - dadas pelas crianças aos itens b e c do Texto 3 da prova, apresentado anteriormente, mantendo fidelidade a suas escritas.

\section{Respostas ao item b do Texto 3}

- Ir reto da letra A até a letra B

- Reto

- Não dá para ir apé porquê o cruzamento A está muito longe do cruzamento B

- Temque olha por os doi lado rápido e passa rápido. Você tem que olha os dois lado e passar

\section{Respostas ao item c do Texto 3}

- Sim o caminho esta serto não esta na contramão o caminho.

- Ele anda na contar mão para chegar mais rapido.

À primeira vista, considerar inadequadas essas respostas poderia estar sugerindo que as dificuldades das crianças em lidarem com usos normativos da linguagem referidos a práticas de orientação e deslocamento espaciais estariam diretamente associadas a outra dificuldade, provavelmente maior, de elas lidarem com usos descritivos em relação a usos informativos da linguagem. Isso porque, além de elas não significarem adequadamente as práticas situadas de localização e orientação espaciais requeridas, todas elas, de certo modo, também transgridem os usos descritivos da linguagem requeridos nesses itens.

Mas a natureza dessa transgressão precisa ser qualificada. A nosso ver, trata-se de uma transgressão a usos descritivos da linguagem induzida pela dificuldade manifestada pelas crianças de realizarem adequadamente práticas situadas de 
localização e orientação espaciais mediadas pelo mapa rodoviário apresentado no Texto 3. Mais ainda, trata-se de uma transgressão que se deve menos à dificuldade de se fazer usos descritivos da linguagem do que à de significar adequadamente as práticas situadas de localização e orientação espaciais requeridas nos itens em foco. Por essa razão, pensamos, essas crianças acionam estratégias de fuga de usos descritivos da linguagem, uma vez que as suas respostas - mesmo que inadequadas - são significativas e compreensíveis, ainda que, quase sempre, transgridam o regime de normatividade culta da escrita em língua portuguesa.

Como se pode constatar, em todas essas 6 respostas acima, as crianças não descrevem o menor trajeto do ponto A ao ponto B explicitando os nomes das ruas que constituem tal trajeto. Entretanto, apenas na segunda e na quarta respostas ao item b, elas parecem mostrar não ter utilizado o mapa do texto como elemento mediador de suas respostas, o que já não ocorre nas outras quatro. De fato, na primeira e na terceira respostas, ao utilizarem as letras A e B para se referir aos cruzamentos das ruas de partida e de chegada do menor trajeto, ou ainda, na quinta e sexta respostas, ao fazerem referência aos sentidos - mão ou contramão - dos percursos nas ruas representadas no mapa, essas quatro crianças mostram estar cientes da diferença entre realizar práticas de deslocamento e orientação espaciais diretamente (isto é, quando os seus corpos efetivamente realizam tais práticas no espaço delimitado pelas ruas do centro de Campinas) e indiretamente (isto é, quando os seus corpos realizam diretamente práticas de leitura e escrita na língua portuguesa, bem como práticas de leitura de mapas rodoviários mediadas por rastros de memória de práticas de deslocamento e orientação espaciais diretamente realizadas).

Esta nossa conjetura se reforça quando observamos a resposta - "Temque olha por os doi lado rápido e passa rápido. Você tem que olha os dois lado e passar" dada por uma das crianças que parece não ter-se apercebido de tal diferença. De fato, quando ela - em vez de descrever explicitamente o menor trajeto utilizando o mapa - diz que é preciso olhar para os dois lados da rua e atravessá-la rapidamente, ela parece colocar-se na situação de estar realizando uma prática situada direta de deslocamento e orientação espaciais nas ruas do centro de Campinas, situação esta que exigiria que o seu corpo se deixasse orientar por regras de segurança no trânsito, e não - como era o requerido pelo item da prova - por regras subjacentes inscritas na imagem (quando vista como um mapa rodoviário) para se deslocar pelo menor trajeto.

A resposta dessa criança, embora considerada inadequada, é significativa e inteligível, visto que, diferentemente do contexto espacial de deslocamento e orientação em uma 'rua real', com muitos veículos trafegando em velocidade, na folha de papel na qual está desenhado o mapa não há necessidade de se "olhar para os dois 
lados" e nem se corre risco de atropelamento. Talvez seja também por essa razão que essa criança, que se coloca numa situação realista de orientação e deslocamento espaciais diretos, tenha desconsiderado o mapa como elemento mediador em sua resposta, uma vez que, em tal situação de 'realismo vivencial' em que ela se coloca, consultas a mapas não seriam mesmo necessárias para se atravessar ruas conhecidas de um "espaço real" visto como familiar.

Analogamente, quando outra dessas crianças diz que "não dá para ir apé porquê o cruzamento A está muito longe do cruzamento B”, a estratégia de fuga de uso descritivo da linguagem que ela aciona, ainda que mediada pelo mapa, parece justificar-se com base na legitimidade que ela atribui ao critério do cansaço físico advindo de se percorrer uma distância por ela considerada longa, critério este que funciona como uma norma mais forte do que a de se fazer um uso descritivo da linguagem solicitado pelo comando textual desse item da prova.

Em outras palavras, as estratégias "realistas" de fuga de usos descritivos da linguagem acionadas por essas duas crianças não podem ser vistas como incapacidade ou falta de competência quer para fazerem usos descritivos da linguagem, quer para fazerem usos normativos da linguagem. Isso porque, na realidade, o que parece ocorrer quando elas acionam tais estratégias "realistas" de fuga é um deslocamento do regime normativo manifesto no jogo de linguagem da imagem (quando vista como um mapa rodoviário). E para onde tais estratégias de fuga remetem essas crianças? O mapa apresenta, através de convenções visuais validadas no campo de atividade humana da cartografia rodoviária, normas suficientes para que as crianças signifiquem, descrevam e pratiquem indiretamente, de modo adequado, o deslocamento e a orientação espaciais requeridos pelo item da prova em foco. Mas é exatamente desse contexto que as crianças fogem, remetendo-se àquele do tráfego de pedestres e veículos no espaço físico delimitado do centro de Campinas, e submetendo seus corpos, portanto, a outro regime de normatividade. Esse novo regime normativo lhes fornece normas - algumas das quais se manifestam em suas respostas - para significarem e praticarem, pelo movimento direto de seus corpos, o deslocamento e a orientação em tal espaço referido, no qual, evitar o cansaço físico e evitar correr o risco de ser atropelado, lhes aparecem como normas a serem seguidas, normas estas vistas como suficientes para substituírem a descrição do próprio percurso requerido pelos itens do Texto 3 da prova.

Tais normas, propósitos e valores que dão sentido às e orientam a realização das práticas de deslocamento e orientação espaciais nesses dois campos de atividade humana - o da cartografia rodoviária, imageticamente encenado no texto da prova, e o do tráfego de pedestres e veículos no espaço físico delimitado pelas ruas do centro de Campinas -, são bem diferentes, ainda que mantenham entre si semelhanças de família. 
Essa nossa análise das respostas das crianças aos dois itens referidos do Texto 3 sugere que os seus baixos desempenhos nesses itens não podem - como costumeiramente se pensa - ser atribuídos a uma suposta falta de "vivência" ou de "experiência" na realização cotidiana de práticas situadas diretas de deslocamento e orientação espaciais em diferentes campos de atividade humana. Não nos permite afirmar também que, devido a esses baixos desempenhos, essas crianças pudessem se mostrar incompetentes para realizar tais práticas, com êxito, em diferentes campos extraescolares de atividade humana. Isso porque tais itens (nos quais elas apresentaram dificuldade máxima) lhes solicitam realizar indiretamente práticas análogas provavelmente realizadas por elas no espaço urbano de Campinas. Por outro lado, tanto a percepção quanto a não percepção, por parte dessas crianças, da diferença entre a realização indireta de uma prática escolar situada e a realização direta de práticas situadas de deslocamento e orientação espaciais em outros contextos, parecem dever-se menos a uma suposta falta de competência em usarem descritivamente a linguagem do que a problematizações inadequadas ou, até mesmo, ausência de problematizações, no contexto escolar, de práticas de deslocamento e orientação espaciais mediadas ou não pelo uso de mapas.

No material didático que circulava na Rede Municipal de Campinas, pudemos constatar a preocupação dos professores em se trabalhar com mapas na sala de aula, ainda que vistos, quase sempre, como um conteúdo curricular de aulas de Geografia, o que faz com que tais práticas acabem reproduzindo aquelas tradicionalmente conformes ao modo disciplinar de se mobilizarem conhecimentos no âmbito da escola. Desse modo, muito provavelmente, os baixos desempenhos das crianças nesses itens possam, em parte, ser explicados pelo modo não usual ou atípico como o mapa do Texto 3 foi mobilizado na prova, relativamente a modos como mapas são usualmente mobilizados em diferentes contextos educativos da rede municipal escolar de Campinas.

Essa atipicidade diz respeito ao fato de as práticas escolares mobilizarem mapas como conteúdos disciplinares estáticos que não dialogam com diferentes práticas culturais indisciplinares que os mobilizam em diferentes campos e contextos de atividade humana, tais como, por exemplo, os campos da navegação marítima e aérea, dentre inúmeros outros.

\section{Gramaticalizar o estilo da pintura ou pintar o estilo gramatical?}

O que esta nossa análise qualitativa comparativa da autogestão corporal de usos preponderantemente alegóricos ou normativos de linguagem por parte das crianças que participaram da Prova Campinas 2010 pretendeu sugerir mais sutil e 
profundamente é a possibilidade de se estabelecerem semelhanças de família entre os modos de autogestão corporal desses dois tipos de usos da linguagem por parte delas.

Essas semelhanças dizem respeito, sobretudo, à insistente fuga do estilo gramatical e, alternativamente, à marcante recorrência ao estilo da pintura, evidenciadas nos modos de autogestão corporal desses dois tipos de usos da linguagem pelas crianças. De fato, constatamos que a percepção da necessidade de se recorrer ao estilo gramatical, na autogestão corporal de usos preponderantemente normativos da linguagem, se mostra pouco frequente, fato este que pode ser constatado pelo recorrente acionamento, pelas crianças, não só em textos alegóricos, mas também em textos normativos, do estilo da pintura e de suas nem sempre permissíveis estratégias mimético-analógicas de fuga dos contextos de atividade humana referidos nos textos da prova a outros contextos de atividade por elas vivenciados ou simplesmente imaginados.

Dado, porém, que, em última instância, todas as estratégias de autogestão corporal de produção de significados são de natureza mimético-analógica, e que, por outro lado, mesmo modos de significar usos alegóricos da linguagem não se fecham à possibilidade de também o serem mediante o recurso a regras cientemente acionadas por um estilo gramatical, a maior dificuldade demonstrada pelas crianças na autogestão corporal de usos preponderantemente normativos em relação a usos alegóricos da linguagem parece estar diretamente relacionada às especificidades e particularidades dos propósitos sociais geradores de usos normativos da linguagem em diferentes contextos de atividade humana. Nesse sentido, se os modos mimético-analógicos de significar segundo os quais opera o estilo da pintura liberam irrestritamente e imprevisivelmente o imaginário performático-ficcional de estabelecimento de conexões semânticas em todos os seres humanos, quaisquer que sejam os modos como constituem e se constituem em comunidades de práticas, as regras com base nas quais opera o estilo gramatical, as quais normatizam a priori o modo como os objetos devem se comportar para que determinados propósitos sociais sejam atingidos, restringem consideravelmente - e, a cada situação contextual, de modo radicalmente diferente - os processos de autogestão corporal de usos de linguagem.

Na escola, essa restrição gramatical ao "voo semântico”, em vez de ser tematizada e problematizada com o propósito de se mostrar a sua legitimidade ou mesmo ilegitimidade em determinadas situações, parece ser ainda mais acentuada pela exigência despropositada de que a gestão corporal de usos preponderantemente normativos da linguagem para significar determinadas práticas culturais que legitimamente os requerem possa ser supostamente avaliada e objetivamente certificada, de modo exclusivo e indireto, pelas práticas igualmente corporais da leitura e da escrita. Talvez, por essa razão, tendo presente o caráter normativo das próprias 
práticas da leitura e da escrita, seja plenamente compreensível que grande parte das crianças responda a essa tentativa da escola de generalização ilegitimamente irrestrita do estilo gramatical de autogestão corporal de significados assimilando-o alegoricamente ao estilo da pintura.

Mas, apesar do acionamento desse modo não intencional de alegorização da resistência, pelo estilo da pintura, manifesto pelas crianças na linguagem e pela linguagem verbal, é preciso também chamar a atenção para o fato de que o imperioso processo de gramaticalização de autogestão corporal de significados não foi propriamente uma invenção da escola. Talvez, fosse melhor entender a própria escola - enquanto perpetuação de um projeto avassalador de aculturação de massas - como um dos mais importantes instrumentos coadjuvantes desse processo de gramaticalização que vem se mostrando, simultaneamente, como processo de matematização, normatização, normalização e globalização cultural (Miguel, 2014).

Se na época de emergência do capitalismo mercantil (Swetz, 1989) - quando ainda não era possível imaginar uma prática de controle normativo da estocagem e circulação de mercadorias pelo código de barras -, o anônimo de Treviso, que intencionalmente comercializava o ensino estritamente verbal da prática corporal do ábaco, ainda podia falar sem conflitos em "arte do comércio", após o advento do “comércio da arte", não seria surpreendente esperar-se também pelo advento coerentemente anônimo de tematização intencional e tensional - pelo estilo da pintura da arte - do "comércio na arte", que agora pode ser significado (Miguel, Vilela \& Moura, 2012) sem mais se recorrer à desnecessária eloquência das práticas de leitura e de escrita ou da 'prática de leitura da prática escrita do ábaco':

\section{BARCODE ART ANÔNIMA}
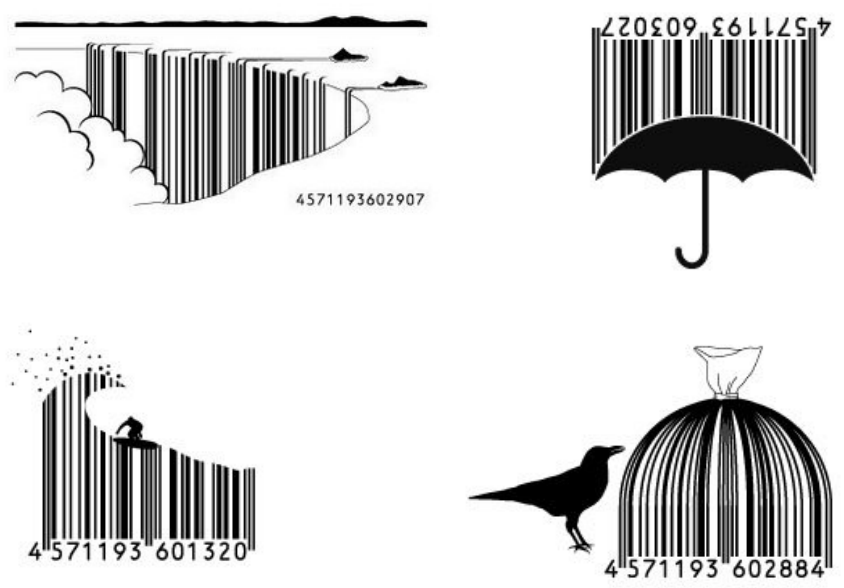

(http://www.eglobel.com/2006/12/o7/barcode-art, acesso em 26/10/2015) 
Assim, como resposta ao insensato e insensível desejo globalizante de gramaticalização dos processos de autogestão corporal da significação - e, por extensão, de gramaticalização cultural do corpo e do olhar -, como se fosse possível, no limite, estender o controle gramatical completamente inequívoco e não ambíguo a todos os jogos humanos de linguagem -, a reação correspondente de autopreservação do estilo da pintura e, portanto, da diversidade cultural, expressa pela visível transfiguração performática do olhar sugerida pela barcode anonymous art não hesitou, por vezes, em assumir uma "assinatura”, ainda que sob a forma de pseudônimo autoral:

\section{BANKSY E A BARCODE ART}

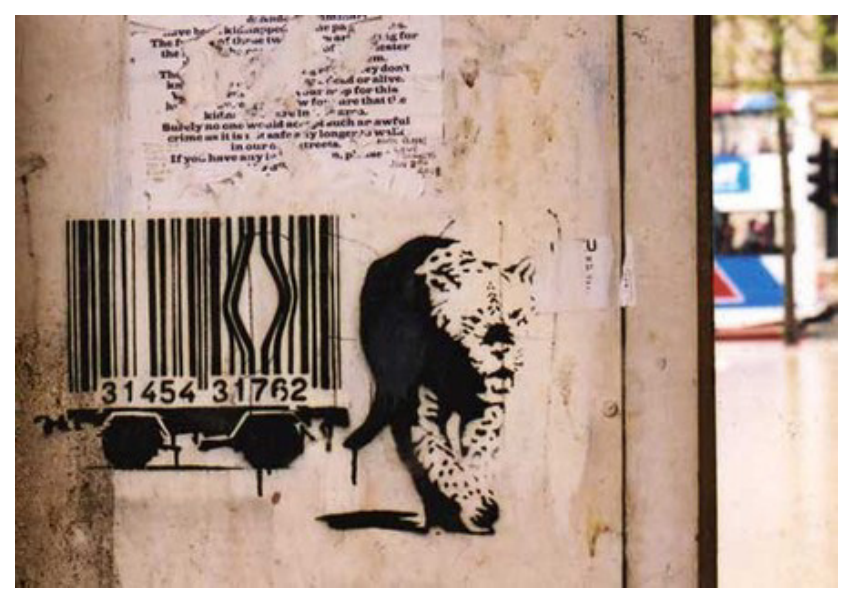

(Banksy, 2006, p. 90)

Esse 'desejo animal' de voo semântico-alegórico manifesto por Banksy (2006, p. 90), pelo estilo da pintura da graffiti art, remeteu-nos - também pelo estilo da pintura - ao seguinte aforismo de Wittgenstein: "Se o leão pudesse falar, nós [humanos] não entenderíamos". Mas, como nós - humanos - falamos, e ao falar, fazemos coisas com palavras ${ }^{22}$, fazemos também o leão falar por nós.

\section{Referências Bibliográficas}

Austin, J. L (1977). How to do things with words. Cambridge: Cambridge University Press.

Banksy (2006). Banksy: wall and piece. London: Century.

Cohen, P. C. (1982). A Calculating People: the spread of numeracy in early America. Chicago: University of Chicago Press.

Condé, M. L. L. (2009). TECHICA/ARS e a produção do conhecimento do homem moderno. In: (Org.). Magno Moraes Mello. Ars, Techné, Technica: a fundamentação teórica e cultural da perspectiva, pp. 115-123. Belo Horizonte, MG: Argvmentvm.

22 Alusão intencional ao livro intitulado How to do things with words de Austin (1977). 
Derrida, J. (1971). La dissémination. Paris: Seuil.

Derrida, J. (2008). Gramatologia. Tradução Miriam Chnaiderman e Renato Janine Ribeiro. São Paulo: Perspectiva.

Duque-Estrada, P. C. (2008). Jacques Derrida. Primeiros passos: da linguagem à escritura. In: Revista Mente, Cérebro E Filosofia. Fundamentos para a compreensão contemporânea da psique. São Paulo: Duetto. n. 12, agosto, p.49-57.

Gebauer, G., Wulf, C. (2004). Mimese na cultura: agir social - rituais e jogos - produções estéticas. Tradução Eduardo Triandopolis. São Paulo: Annablume, 1a a. Edição.

Glock, H.-J. (1998). Dicionário de Wittgenstein. Rio de Janeiro: Zahar.

Haddock-Lobo, R. (2008). Derrida e o labirinto de inscrições. Porto Alegre: Editora Zouk, 2008.

Haddock-Lobo, R. (2011). Para um pensamento úmido: a filosofia a partir de Jacques Derrida. Rio de Janeiro (RJ): Nau: Ed. PUC-Rio.

Lave, J. (2003). Cognition in Pratice: Mind, Mathematics and culture in everyday life. Cambridge: Cambridge University Press.

McDonald, H. (2001). Wittgenstein, Narrative Theory, and Cultural Studies. Telos: Critical Theory of Contemporary, n. 121 p. 11-53.

Miguel, A. (2014). Is the mathematics education a problem for the school or is the school a problem for the mathematics education? Brazilian Society for Mathematics Education: RIPEM - International Journal for Research in Mathematics Education, V. 4, N. 2, pp. 5-35.

Miguel, A. (2015). Historiografia e terapia na cidade da linguagem de Wittgenstein. No prelo. Bolema.

Miguel, A., Vilela, D. S. \& Moura, A. R. L. (2012). Problematização indisciplinar de uma prática cultural numa perspectiva wittgensteiniana. Revista Reflexão e Ação. Santa Cruz do Sul, v. 20, n. 2, pp. 1-26.

Moura, A. R. L., Miguel, A., Silva, L. L. M. \& Ferreira, N. S. A. (2015a). Prova Campinas 2008: uma avaliação das práticas escolares em língua portuguesa e matemática nos anos iniciais da Rede Municipal Escolar de Campinas. E-Book: ISBN: 978-85-7713166-2. Campinas, SP: FE/UNICAMP: Prefeitura Municipal de Campinas. Secretaria da Educação.

Moura, A. R. L., Miguel, A., Silva, L. L. M. \& Ferreira, N. S. A. (2015b). Prova Campinas 2010: um modo indisciplinar de avaliar as práticas escolares nos anos iniciais da rede municipal escolar de Campinas. E-Book: ISBN 978-85-7713-168-6. Campinas, SP: FE/UNICAMP: Prefeitura Municipal de Campinas. Secretaria da Educação.

Nietzsche, F. W. (2008). A vontade de poder. Tradução de Marcos Sinésio Pereira Fernandes e Francisco José Dias de Moraes. Apresentação de Gilvan Fogel. Rio de Janeiro: Contraponto.

Nietzsche, F. W. (2001). Além do bem e do mal ou prelúdio de uma filosofia do futuro. Tradução de Márcio Pugliesi. Curitiba (PR): Hemus S.A. 
Saidan, A. S. (1975). The arithmetic of al-Uqlïdisī. Translated and annoted by A. S.Saidan. Dordrecht (Holland)/Boston (EUA): D. Reidel Publishing Company.

Salles, J. C. P. S. (2005). Filosofia e terapia em Wittgenstein. Analytica, vol. 9, n. 2, pp. 88-112.

Suarez, R. (2011). Nietzsche e a linguagem. Rio de Janeiro: 7 Letras.

Souza, E. S. (2004). A prática social do cálculo escrito na formação de professores: a história como possibilidade de pensar questões do presente. Tese (Doutorado) - Faculdade de Educação, Universidade Estadual de Campinas, Campinas.

Swetz, F. (1989). Capitalism and Arithmetic. The New Math of 15th Century. Illinois: Open Court Publishing Company.

Wittgenstein, L. (1987). Observaciones sobre los fundamentos de la matemática. Versión de Isidoro Reguera. Madrid: Alianza Editorial.

Wittgenstein, L. (2009). [Philosophische Untersuchungen. English]. Philosophical investigations/ Ludwig Wittgenstein; translated by G.E.M. Anscombe, P.M.S. Hacker, and Joachim Schulte. - Rev. $4^{\text {th }}$. ed. / by P.M.S. Hacker and Joachim Schulte.UK: Blackwell Publishing Ltd.

Wittgenstein, Ludwig. Investigações filosóficas. Trad. José Carlos Bruni. São Paulo: Nova Cultural, 1979.

Wulf, C. (2013). Homo Pictor: imaginação, ritual e aprendizado mimético no mundo globalizado. Tradução e Prefácio por Vinicius Spricigo. São Paulo: Hedra.

Submetido em: 15/06/2015

Aprovado em: 21/09/2015 